\title{
LIQUIDATION-REINCORPORATION: A RECENT DEVELOPMENT
}

\author{
RICHARD D. HOBBET*
}

No one problem has plagued the administration of Subchapter C of the Internal Revenue Code ${ }^{1}$ as much as the multiplicity of transactions that fall generally under the "liquidation-reincorporation" rubric. In recent years a rash of cases have involved rather sophisticated devices for steering through the interstices of Subchapter $C$ in order to bail out corporate earnings and profits without dividend treatment. The courts, particularly the Fifth Circuit Court of Appeals ${ }^{2}$ and occasionally the Tax Court, ${ }^{3}$ have struggled to formulate equally sophisticated responses to the bail-out schemes to justify the congressional faith that the Internal Revenue Service and the courts could cope with this problem without a "special statutory provision." 4

Recently the case of the Estate of Henry P. Lammerts ${ }^{5}$ created a substantial division among the judges of the Tax Court as to the appropriate judicial doctrine to apply to liquidation-reincorporation situations. The majority of the court, in an opinion written by Judge Erwin, relied on the traditional, rigid approach to these cases, an approach which accepts the independent identity of each taxpayer

* Professor of Law, Duke University School of Law. B.A. 1949, J.D. 1951, University of lowa. Corporations Editor, Journal of TAXation.

1. INT. REV. CODE of 1954, $\S \S 301-95$.

2. See, e.g., Reef Corp. v. Commissioner, 368 F.2d 125 (5th Cir. 1966), cert. denied, 386 U.S. 1018 (I967); Davant v. Commissioner, 366 F.2d 874 (5th Cir. 1966), cert. denied, 386 U.S. 1022 (1967).

3. See, e.g., James Armour, Inc., 43 T.C. 295 (1964); John G. Moffat, 42 T.C. 558 (1964), affd. 363 F.2d 262 (9th Cir. 1966), cert. denied, 386 U.S. 1016 (1967).

4. H.R. REP. No. 2543, 83d Cong., 2d Sess. 4 I (1954). The Senate-House conference committee on the 1954 Code rejected legislation to deal with the liquidation-reincorporation problem. As the managers of the bill in the House explained:

The House bill in section 357 contained a provision dealing with a device whereby it has been attempted to withdraw corporate earnings at capital gains rate by distributing all the assets of a corporation in complete liquidation and promptly reincorporating the business assets. This provision gave rise to certain technical problems and it has not been retained in the bill as recommended by the accompanying conference report. . . . [A]t the present time, the possibility of tax avoidance in this area is not sufficiently serious to require a special statutory provision. It is believed that this possibility can appropriately be disposed of by judicial decision or by regulation within the framework of other provisions of the bill.

5. 54 T.C. 420 (1970). The Tax Court decision is currently on appeal to the Court of Appeals for the Second Circuit. P-H 1971 Fed. Taxes, Citator 10, 32. 
involved in the transaction. The various steps taken in consummating the transaction are then treated, under the step transaction doctrine, as an integrated series of steps leading to a single transaction; the resulting transaction is tested by the traditional reorganization concepts of sections $351-68^{6}$ to determine the appropriate tax treatment. If no reorganization can be found, then each step is treated as a separate transaction and liquidation and distribution concepts of sections 331-38 will normally apply, resulting in capital gain treatment for the assets removed from the corporation.

Judge Sterrett, in a dissenting opinion joined by Judge Dawson, approached the case along the lines originally developed by the Commissioner in Revenue Ruling.61-156 and more recently used by the Fifth Circuit Court of Appeals in deciding Reef Corp. $v$. Commissioner $^{8}$ and Davant v. Commissioner. ${ }^{9}$ Judges Sterrett and Dawson differ with the majority both in their willingness to treat several taxpayers as having a substantial identity and to separate one transaction as functionally independent from the remaining steps. Otherwise they apply traditional reorganization concepts.

Judge Tannenwald, in a dissenting opinion joined by Judge Simpson, developed further a theory which he set forth earlier in Casco Products Corp. ${ }^{10}$ That decision ignored a liquidation transaction and treated two separate corporations as substantially identical for tax purposes, thus bypassing completely the reorganization provisions of the Code. ${ }^{11}$

Estate of Lammerts thus articulates the three major positions which courts are now using in liquidation-reincorporation problems. Because of the currency and importance of these three separate positions, an analysis of them may be beneficial both for practitioners planning bail-out transactions and for the Internal Revenue Service and the courts in their attempt to administer the revenue laws equitably. Such an analysis should be of particular interest to

6. See generally B. Bittker \& J. Eustice, Federal Income Taxation of Corporations \& SHAREHOLDERS, ch. 12 (2d ed. 1966).

7. 1961-2 CuM. BuLl. 62.

8. 368 F.2d 125 (5th Cir. 1966), cert. denied, 386 U. S. 1018 (1967).

9. 366 F.2d 874 (5th Cir. 1966), cert. denied, 386 U. S. 1022 (1967).

10. 49 T.C. 32 (1967). Judges Raum, Withney, Atkins, Scott, and Featherston dissented.

11. Lammerts also involved questions about whether a redemption of preferred stock a year after the liquidation was equivalent to a dividend and whether the estate had reasonable cause for the late filing of a fiduciary income tax return. Neither question caused the court any great difficulty, and neither was mentioned in the dissenting opinions. 
practitioners because it is probable that the sequence of transactions which allowed a bail-out of corporate earnings following Henry Lammerts' death was planned by Lammerts' tax counsel. If this was not in fact the case, it could have been, and practitioners today will certainly be wrestling with the question of whether to use a Lammertstype approach in attempting to achieve a similar result for clients owning closely-held corporations.

\section{The Lammerts Plan}

Henry Lammerts, at the age of 70 , executed a will in which he directed that the executors of his estate liquidate a corporation in which he then owned over 85 percent of the outstanding stock. The balance of the shares were owned by his son, Parkinson, who was to receive an interest in the operating assets of the corporation from Henry's estate such that he would then own an undivided 25 percent interest in those assets. The will pointed out that it was Parkinson's desire to continue the automobile agency which the corporation was then operating. The executors of the estate, named by the will, were Henry's wife, Hildred, and Parkinson, the only two devisees of the operating assets of the corporation.

Three years after the will was written, Henry died; pursuant to the terms of the will, the executors of the estate, then holding the majority interest of the stock of the corporation as fiduciaries, adopted a plan of dissolution for the corporation. Beginning on December 27, 1961, the remaining steps for achieving the liquidation and reincorporation proceeded with dispatch. On that day the old corporation filed a change of name with the Department of State. On January 2, 1962, the corporation's full liquidation was achieved by distribution of all of its assets to the executors of the estate. Immediately thereafter, the executors distributed the operating assets of the automobile sales and service agency to Hildred and Parkinson in the portions provided by the will. Then, also on January 2, 1962, the third transfer took place, when Hildred and Parkinson, acting for themselves and not as executors, transferred their interests in the operating assets of the automobile agency to the new corporation in exchange for stock of that corporation. Hildred received 1,498 shares of preferred stock in this transaction, and Parkinson received 461 shares of common stock. Thereafter, Parkinson was the sole common shareholder and Hildred was the sole preferred shareholder of the corporation. Held out of the new corporation were accounts receivable in the amount of $\$ 2,688$, a 
loan to the shareholders in the amount of $\$ 9,979.81$, and real estate having a book value of $\$ 78,591.65$; most of these assets were retained by Hildred.

The results of these events were that the business of the original corporation was continued, uninterrupted, by the new corporation; that the ownership of the business was continued, uninterrupted, by members of the Lammerts family; and that corporate assets were removed from the corporation in what the taxpayer hoped was a taxfree transaction. Since the basis of the shares of the old corporation would be stepped-up upon Henry's death, the purported liquidation would result in no gain or loss to the shareholders; the earnings and profits of the old corporation would receive a new basis. The Commissioner understandably sought to tax the shareholders on the receipt of a dividend, or a distribution in connection with a reorganization to be treated as a dividend under section 356 . He encountered serious problems in this attempt because of the limited means at his disposal for attacking liquidation-reincorporation transactions. The subsequent litigation, however, triggered a split within the Tax Court and resulted in three separate approaches to this recurring problem.

The Traditional, Separate-Entity Approach Adopted by the MAJORITY

Judge 1rwin, writing for the majority of the Tax Court, took the traditional approach to this type of case by strictly adhering to the independent existence of two corporate taxpayers - the old corporation and the new corporation. Despite the fact that the old corporation was liquidated and dissolved on the very same day that most of its assets were transferred to the new corporation and that the corporate business contined without interruption, the Tax Court found that on January 2, 1962, one taxpayer's life had ended and a new taxpayer's life had begun. Accordingly the tax results were made to depend upon whether the liquidation of the old corporation was considered as a separate taxable transaction or whether it was simply one step in a liquidation-reincorporation transaction which would be within one of the definitions of a corporate reorgnization to be given at least partial nonrecognition treatment under Subchapter $C$ of the Internal Revenue Code. Finding no reorganization, the majority upheld the claim of the taxpayer.

There is historical precedent for this approach of treating new 
corporate entities as separate and distinct from their predecessors. Marr v. United States, ${ }^{12}$ decided in 1925, involved a New Jersey corporation which succeeded completely to the assets and business of a Delaware corporation. The New Jersey corporation then exchanged its stock for stock of the Delaware corporation in what would now be an " $F$ " reorganization, "a mere change in [the] place of organization." 13 The Supreme Court ruled, however, that this exchange of stock was a taxable transaction because the two corporations were essentially different. Justice Brandeis, speaking for the Court, stated that:

A corporation organized under the laws of Delaware does not have the same rights and powers as one organized under the laws of New Jersey. Because of these inherent differences in rights and powers, both the preferred and the common stock of the old corporation is an essentially different thing from stock of the same general kind of the new. ${ }^{14}$

He found support for this decision in three earlier decisions of the Supreme Court: United States v. Phellis, ${ }^{15}$ Rockefeller v. United States, ${ }^{16}$ and Cullinan v. Walker ${ }^{17}$ in each of these cases he indicated that the Court had considered a new corporate entity to be a separate taxpayer so that an investment in one was substantially different than an investment in the other, and an exchange of stock in one for stock of the other was recognized as a taxable exchange. Brandeis found it necessary to distinguish only Eisner v. Macomber ${ }^{18}$ on the grounds that there had clearly been no change in the corporate identity, and Weiss $v$. Stern, ${ }^{19}$ on the grounds that the new entity had only technical existence and that "[t]he corporate identity was deemed to have been substantially maintained because the new corporation was organized under the laws of the same state, with presumably the same powers as the old." ${ }^{20}$ The four dissenting justices in Marr felt that the case fell squarely within the doctrine of Weiss $v$. Stern and, since the business and assets of the corporation had not materially changed, the shareholders' investment had not changed sufficiently to result in a

\footnotetext{
12. 268 U.S. 536 (1925).

13. INT. Rev. CoDE of 1954, § 368(a)(l)(F).

14. 268 U.S. at 541.

15. 257 U.S. $156(1921)$.

16. 257 U.S. 176 (1921).

17. 262 U.S. 134 (1923).

18. 252 U.S. 189 (1920).

19. 265 U.S. 242 (1924).

20. 268 U.S. at 541 .
} 
taxable transaction. Although Marr does not deal with a bail-out of corporate earnings in a liquidation-reincorporation setting, it does deal with whether, in the absence of a statutory non-recognition provision, an investment in the old corporation should be considered to be so different from an investment in the new one that a taxable exchange has taken place. Had the Court found that there was no income to be recognized here, it might well have led to a broader concept of substantial identity or continuity for related corporate entities.

Such a broader concept would have easily accommodated the idea that the new Lammerts corporation was essentially the same as the old and that, for tax purposes, no real change of investment interest had taken place at the shareholder level. Accordingly, any assets removed from the corporate solution would have to be treated under the distribution or liquidation provisions of the Code and probably would not qualify for capital-gain treatment. ${ }^{21}$ The Tax Court confrontcd and rejected this argument in Joseph C. Gallagher. ${ }^{22}$ Judge Opper, writing for a majority of the court, said:

The concept of a continuation of the existing business through a section 331 liquidation, coupled with an intercorporate transfer, falls into the general area of corporate reorganizations, so that it is in the so-called rcorganization sections, if anywhere, that we should expect it to be dealt with.

....

... [G]enerally speaking, it is exactly where the same enterprise is in essence wholly or partly continued even after some more or less radical change in its organization or conduct that it is the purpose of the so-called "reorganization" section of the law to operate. The basic approach of the complicated series of enactments incorporated in the 1954 code appears to be that all such situations are to be tested by the "reorganization" portion of the statute, and that it was intended that if a transaction of a similar kind does not fall within them, but lies in the general area of arrangements which may, in effect, constitute the continuation of an existing business, it shall be treated as a transaction giving rise to gain or loss and not as a distribution. ${ }^{23}$

The Tax Court, therefore, rejected the idea that, where the corporate business contined and a corporate transfer took place, the liquidation of the old corporation could be ignored. Had it accepted that concept, the assets removed from corporate solution would have been treated

21. INT. REv. CODE of 1954, $\S 301-38$. Most retained assets under this concept would probably be dividends under section 301 .

22. 39 T.C. 144 (1962).

23. Id. at I57-58. 
as received by the shareholders in a simple dividend distribution from the corporation.

Thus, precedent provided ample justification for the holding of the majority of the Tax Court that the old and new corporations were different taxable entities. In reality, the Court did little more than fall back on what it had previously said in Gallagher and reaffirmed in Hyman H. Berghash. ${ }^{24}$ Since the Second Circuit, in Berghash, resoundingly affirmed the separate-entity approach taken by the Tax Court in Gallagher, ${ }^{25}$ it would appear that Lammerts will be affirmed on appeal. However, since there was a substantial change in ownership in Berghash, it may be distinguishable from Lammerts on the grounds that, although there was a change in ownership, the change was entirely within a close family group. Lammerts could also be viewed as a far more flagrant use of the liquidation-reincorporation device to obtain a bail-out of corporate earnings. These distinctions should at least give the Second Circuit cause to reconsider its rejection of the Commissioner's approach in Berghash and consider whether the approach of either of the dissenting judges of the Tax Court would be a more appropriate way to deal with the Lammerts case.

\section{The Functional Relation Approach}

In addition to taking a strict view of the separate identity of the two corporations, the majority found it necessary to take a similarly strict view with respect to the separateness, as taxpayers, of the estate and its two beneficiaries, Hildred and Parkinson Lammerts. ${ }^{26}$ It was on this latter point that Judge Sterrett disagreed with the majority, permitting him to find that a " $D$ " reorganization ${ }^{27}$ had occurred. The majority was probably influenced by the fact that the attribution of ownership rules of section 318 are not generally applicable to the

24. 43 T.C. 743 (1965), affd. 361 F.2d 257 (2d Cir. 1966).

-25. In the Berghash case the Second Circuit said:

We are in complete agreement with the Tax Court's resolution of this issue; its interpretation reflects the normal meaning of the words "complete liquidation" in sections 331 and 337. To adopt the Commissioner's contention would do violence to the plain meaning of the statutes . . . We can only conclude that the Tax Court's result is consistent with the intent of Congress, which considered the reincorporation problem in 1954 but rejected specific proposals for dealing with it as the Commissioner suggests. 361 F.2d at 260. The Ninth Circuit Court of Appeals has recently endorsed this view in Breech v. United States, 439 F.2d 409 (9th Cir. 197I).

26. 54 T.C. at 432 n. 14 .

27. INT. REv. CODE of 1954, § 368(a)(1)(D). 
Subchapter $C$ area. Since section 318 specifically provides for those cases where ownership may be attributed between estates and their beneficiaries and since section 318 does not apply, the court was technically and statutorily justified in finding that the estate was a separate taxpayer from its two beneficiaries and that the ownership of stock by the estate should not be considered to be indirect ownership of that same stock by Hildred and Parkinson. ${ }^{28}$ Judge Sterrett, however, felt that, in determining whether there was the necessary "control" for purposes of the reorganization provisions, ${ }^{29}$ it was appropriate to consider that the stock of the old corporation owned by the estate was equitably owned by the two beneficiaries. Under that view, the common stock of the old corporation then belonged entirely to Hildred and Parkinson prior to the liquidation of the old corporation. Linking the liquidation and reincorporation together as a single transaction, it appears that there was a transfer of substantially all of the assets of the old corporation to a new corporation where immediately after the transfer the shareholders of the old corporation are in control of the new corporation, the definition of a " $D$ " reorganization. The final condition of the " $D$ " reorganization, a distribution qualifying under section 354 , was also met; all of the stock and securities deemed received in the transaction, as well as all of the other assets of the corporation, were considered distributed in the complete liquidation of the old corporation.

This would have been a pyrrhic victory for the Commissioner without use of the "functional independence" doctrine developed by the Fifth Circuit in Reef and Davant to determine that the distribution of assets left out of corporate solution was not a part of the " $D$ " reorganization. If it were a part of the reorganization, the property distributed would have been considered boot and taxed under section 356(a) as ordinary income only to the extent of the gain on the exchange. Since the basis for most of the stock of the old corporation was stepped up because of Henry's death, ${ }^{30}$ there would have been no gain on the exchange of stock and none of the boot could

28. See generally Ringel, Surrey \& Warren, Attribution of Stock Ownership in the Internal Revenue Code, 72 HARv. L. Rev. 209 (1958).

29. INT. REv. CODE of $1954, \S 368$ (a)(1)(D) requires that the transferor corporation or its shareholders be "in control of" the transferee corporation immediately after the transfer. Section 368(c) defines "control" as ownership of stock possessing 80 percent of the voting power in the corporation and 80 percent of the total stock.

30. Id. § 1014. 
have been taxed as ordinary dividend income. Judges Sterrett and Dawson felt, however, that the removal of property from the corporate solution was a transaction having no necessary relationship to the steps constituting the " $\mathrm{D}$ " reorganization and was therefore a separate distribution of assets. Treated in this way as a step functionally independent of the reorganization, the distribution of the real estate, debt, and receivables was a simple distribution of a dividend-in-kind, fully taxable to the shareholders as ordinary income without regard to the basis of the stock. ${ }^{31}$

There are obvious difficulties in determining that a particular step, which is only one of several in a planned course of action, is functionally independent of the other steps. Unless there is some objective way to determine that a step should not be treated as part of a unitary transaction, courts will be reluctant to adopt this theory; the mere fact that the revenue will thereby be increased is not likely to be sufficient justification. If the step transaction doctrine ${ }^{32}$ is applied in the case because all the steps are taken pursuant to one plan, what basis is there for choosing among the planned steps only those which, if taken together, would result in the greatest revenue? Judge Sterrett's opinion did not deal at length with this problem; he simply stated that the distribution appeared to be an event separate and distinct from the reorganization. The judge relied on the Fifth Circuit's statement in Reef that "the test of whether events should be viewed separately or together as part of the single plan is not temporal but is functional" 33 and concluded that "[a]pplying this standard to the instant case, I fail to see how the dividend distribution can be said to be either necessary to or any other way rationally related to the reorganization." 34 In some cases, such a distribution may be vitally necessary to a transaction in order to achieve agreement between the parties to the exchange; in other cases, it may simply be a desired part of the transaction. The reorganization provisions contain no explicit

31. Id. $\S 301(\mathrm{a}), 301(\mathrm{c}), 316$.

32. Basically, this is the doctrine that "the law will not permit what is essentially a single transaction to be broken up into component parts with each of the component steps being given independent significance." Hobbet, The Step Transaction Doctrine and Its Effect on Corporate Transactions, Proceedings of tHe 19Th ANnUAL Tulane INST., 102, 103 (1970). The converse is also part of the doctrine. See also Mintz \& Plumb, Step Transaction in Corporate Reorganizations, N.Y.U. 12TH 1NST. ON FED. TAX. 247 (1954); Paul \& Zinet, Step Transactions, Selected Studies in Federal Taxation 200 (2d Series 1938).

33. 368 F.2d at 134.

34. 54 T.C. at $456(1970)$. 
recognition of a distinction between the two and seemingly deal with it as a boot distribution under section 356 in either case. Thus, to say that the distribution here was not necessary, nor rationally related to the reorganization is to suggest that a distribution that is part of the plan of reorganization will not qualify for treatment as boot under section 356 if it is not a necessary part of the plan and is included only because the parties consider it desirable. However, the Tax Court has consistently refused to rule that the tax results of such a transaction depend on this distinction between necessity and desirability. ${ }^{35}$

This is not to say that Judge Sterrett's approach has no merit. However, the inquiry into the criteria of "functionally unrelated" should be extended beyond the simple question of whether the challenged step is part of the reorganization. ${ }^{36}$ This inquiry could be advanced by giving greater attention to the fact that the Internal Revenue Code describes many taxable events, some of which may often be seen to overlap. Reorganization transactions or exchanges are only one of a variety of taxable events described in the Code; another event is a distribution of a taxable dividend. When an event examined in isolation meets the definition of a dividend distribution but, when combined with other steps, appears also to be a boot distribution, the court must choose one description of the transaction over the other. The Code provides no help in making the choice, for it states no preference for one over the other; it only describes the two alternatives, leaving the choice to the court.

Perhaps the motivation for including the various steps in a single plan will be a useful basis on which the court can make its choice. It is quite possible in one case for a reorganization transaction to be coupled with a dividend distribution in order to avoid the tax on the dividend, whereas in another case a cash distribution might be coupled with what would otherwise be a reorganization transaction in order to avoid the application of the reorganization provisions. ${ }^{37} \mathrm{An}$ example of the first case would be a corporation which wanted to make a dividend distribution to shareholders at a time when the fair market value of the stock of the corporation was at or near the basis of the stock in the hands of the shareholders. To accomplish this with

35. This distinction was most recently rejected in American Mfg. Co., 55 T.C. 204, 224-29 (1970). See notes 67-69 infra, and accompanying text.

36. Hobbet, supra note 32.

37. For example, cash or other property might be thrown in simply to defeat what would otherwise be a "B" reorganization, INT. Rev. CODE of 1954, $\$ 368(\mathrm{a})(\mathrm{I})(\mathrm{B})$. 
little tax impact, the corporation might adopt a plan of recapitalization and go through an " $E$ " reorganization, ${ }^{38}$ coupling the exchange of the shareholders' stock with a distribution of securities. Since there would be little or no gain on the exchange of shares, a limited dividend equivalence would be found under section $356 .{ }^{39}$ In such a case, can it be said that the dividend distribution of the securities is functionally related to the recapitalization? Neither plays a necessary role in achieving the commercial aspects of the other; the reorganization itself plays a functional role only to the extent that it may prevent a tax on the dividend distribution. ${ }^{40}$ The absence of functional relation appears by investigating the motivation of the parties in electing to couple the distribution with a recapitalization.

In this way, motivation could be useful in helping to determine functional independence. If the courts were to adopt this concept and use it regularly in reorganization cases, a tax planner would have to be wary of any transaction which would result in assets being removed from the corporate solution where this removal is not useful to the consummation of the commercial aspects of the transaction. The inquiry into taxpayer motivation then becomes a determination of whether the distribution would have been useful in achieving the commercial goals of the transaction without consideration of any tax savings by the shareholders which might occur. If a commercially acceptable motivation is found, then the distribution would appear to be functionally related to the reorganization.

An analogy to this investigation of motive can be found in the cases dealing with alleged sham transactions where the only profit anticipated in the transaction is the saving of taxes. For example, in

38. $I$ d. $\S 368(\mathrm{a})(\mathrm{I})(\mathrm{E})$.

39. This would be so even though, since no securities were surrendered, the securities received are in excess of the face value of the securities surrendered.

40. With motive isolated in this way it might be answered that the recapitalization or reorganization would fail in any event because there is no business purpose to the reorganization. However, the practicality of the situation is such that the business purpose doctrine for corporate reorganization is easily met and the tax planner should have little difficulty in stating an adequate business purpose for the recapitalization in order to support the non-recognition status of the exchange. Therefore, since the reorganization itself would appear to have a business purpose other than mere tax avoidance, there may be little or no way for the court to separate the distribution from the reorganization and then to determine that the distribution was coupled with the reorganization primarily to take advantage of an opportunity to avoid the dividend tax. As such it would not appear to be serving any function in the reorganization transaction and could be said to be functionally unrelated to it. 
Knetsch v. United States, ${ }^{41}$ the Supreme Court disallowed a taxpayer's claim for interest deductions because it found that the loan transaction on which the interest was paid was a fiction. It made this finding primarily because it could see no commercial motivation for the taxpayer to enter into the transaction except for the profit which he expected from tax savings. Since the loan was a sham, the interest payments did not fit the statutory requirements for interest deduction ${ }^{42}$ and were not allowed.

This type of case does not involve a choice between two different sections of the Code, but it does examine motivation and commercial substance to determine whether a transaction described in the Code has occurred. It is possible to use a similar examination to reject the idea that a boot distribution has been made as part of a reorganization if there is no commercial, ${ }^{43}$ non-tax motivation for including the distribution in the reorganization. If it is not a boot distribution, there is no problem under ordinary dividend concepts in finding that it fits within the statutory definition of a "dividend." 44

\section{The Commercial Motivation Approach}

Judge Tannenwald's approach to this case is a basic departure from the traditional concepts to which both the majority and Judges Sterrett and Dawson felt bound to adhere. Critizing the majority opinion as a "supine acceptance of the tyranny of labels" and noting that Judge Sterrett "lends credence to this analysis by focusing upon the reorganization provisions," 45 Judge Tannenwald, joined by Judge Simpson, challenged the claim that the liquidation and dissolution of the old Lammerts corporation needed to be treated as a liquidation transaction within section 331 of the Internal Revenue Code. In Joseph C. Gallagher, ${ }^{46}$ the Tax Court described this as an either-or proposition: the dissolution either had to be part of a reorganization or it must be accorded section 331 treatment as a liquidation. The "supine acceptance of this tyranny of labels" was said "to escalate

41. 364 U.S. 361 (1960).

42. INT. REv. CODE of 1954, § 163(a).

43. The commercial motivation test would be stricter than the business purpose test, see note 40 supra, and would focus on the individual steps of the iransaction rather than on the transaction as a whole as the business purpose test does.

44. INT. REV. CoDE of 1954, § 316(a); cf. id. §§ 301-02.

45. 54 T.C. at 447.

46. 39 T.C. 144 (1962). 
one prong of Joseph C. Gallagher, and Hyman H. Berghash ${ }^{47}$. . . from the level of a distinguishable rationale to a mandated doctrine of wide application."48 This contention appears to have merit since greater weight traditionally has been accorded state law concepts in interpreting the term "liquidation" as used in section 331 than in interpreting the term "interest" as used in section 163. Yet, both the dissent of Justice Douglas in Knetsch $v$. United States ${ }^{49}$ and the opinion of the Tax Court in Lammerts are bottomed on an attempt to reconcile the Code with state law. In Knetsch, the Supreme Court was faced with a loan and annuity transaction which was valid under state law, and indeed called for the lender to receive a profit as a result of interest on the loan; Justice Douglas felt that this fact was controlling. However, the Court rejected the idea that state law descriptors ended the inquiry into the meaning of "indebtedness" and "interest" for purposes of federal tax law.

In Lammerts, however, the majority opinion remains just as rigidly bound to state law concepts of liquidation as was Justice Douglas to state law concepts of indebtedness. Once the Court decided that the events under consideration did not fit any statutory definition of reorganization, the liquidation and dissolution of the corporation under state law stood alone as a single event and the Court did not inquire further whether the liquidation was sufficient under section 331 of the Code. It was this dogmatic acceptance of state law concepts that Judge Tannenwald rejected, saying that the criteria of "form versus substance" were more than adequate to compel the conclusion that the requirements of section 331 had not been met because the liquidation was a sham..$^{50}$

It is, of course, a familiar shibboleth of federal tax law that interpretation of the Internal Revenue Code is not dependent on state law or common law concepts. Almost forty years ago, in Burnet v. Harmel, ${ }^{51}$ the Supreme Court said:

Here we are concerned only with the meaning and application of a statute enacted by Congress, in the exercise of its plenary power under the Constitution, to tax income. The exertion of that power is not subject to State control. It is the will of Congress which controls, and the expression of its will

47. 43 T.C. 743 (1965).

48. 54 T.C. at 447.

49. 364 U.S. at 370 . See notes $41-44$ supra and accompanying text.

50. 54 T.C. at 447.

51. 287 U.S. 103 (1932). See also Commissioner v. Duberstein, 363 U.S. 278 (1960). 
in legislation, in the absence of language evidencing a different purpose, is to be interpreted so as to give a uniform application to a nation-wide scheme of taxation . . . State law may control only when the federal taxing act, by express language or necessary implication, makes its own operation dependent upon state law. ${ }^{52}$

The Second Circuit Court of Appeals, which now ha's Lammerts on appeal, strongly reaffirmed this principle in 1965 in Borax's Estate $v$. Commissioner. ${ }^{53}$ There the court considered the validity of a marriage for purposes of determining the right to file a joint return for federal income tax purposes. The State of New York, which had jurisdiction over the taxpayer, had declared that the taxpayer's Mexican divorce was invalid and that his subsequent remarriage was, therefore, also invalid. Had the court of appeals accepted this determination as binding for federal tax purposes, it would have affirmed the holding of the Tax Court that the parties could not file a joint return. Instead, it held that the decree of divorce was valid for federal tax purposes and that the taxpayer's remarriage must also be recognized for tax purposes. It noted two situations on which it did not intend to rule, and these reservations are themselves instructive.

The first situation which was distinguished was the case where the same jurisdiction which rendered the divorce subsequently found it to be invalid. The court said that it would not rule on whether such a divorce could be considered valid for tax purposes, thus clearly indicating its unwillingness to be bound by state law. On the other situation, the court said:

Secondly, we are not dealing with a situation where the rendering jurisdiction's concept of a divorce is totally alien to that contemplated by the tax laws. The test would not be whether the divorce would be declared invalid in every state, but rather whether the divorce frustrated the revenue purposes of the tax laws. ${ }^{54}$

If it is possible that the concepts of divorce and marriage under federal tax law may be alien to the state law concepts which in fact determine the rights, duties, and status of individuals in the marital relationship, it should not be difficult to accept Judge Tannenwald's thesis that not all corporate liquidations undertaken according to the laws of the state of incorporation must be accorded section 331 treatment.

52. 287 U.S. at 110.

53. 349 F.2d 666 (2d Cir. 1965), cert. denied, 383 U.S. 935 (1966).

54. 349 F.2d at 672 . 
Judge Tannenwald used motivation as a test to determine the reality of the liquidation for federal tax purposes. He made no attempt to distinguish between corporate and shareholder motivation in making that determination, since the record was devoid of evidence on either factor; he believed that the presence of a commercial motivation of some sort was necessary to qualify for section 331 capital gain treatment. Since there was no such motivation in this case, he found that the liquidation was not within section 331 .

Judge Tannenwald was troubled in this holding by the fact that the Supreme Court has recognized the legitimacy of corporate liquidations even though motivated solely by tax considerations; his example was United States v. Cumberland Public Service Co. ${ }^{55}$ His reference was undoubtedly to the Court's statement that

Congress has imposed no tax on liquidating distributions in kind or on dissolution, whatever may be the motive for such liquidation. Consequently, a corporation may liquidate or dissolve without subjecting itself to the corporate gains tax, even though a primary motive is to avoid the burden of corporate taxation. ${ }^{.5}$

However, this statement should not be taken to mean that a liquidation under state law must always be recognized as such for all tax purposes. Even though it might be accorded tax-free status at the corporate level pursuant to the dictum quoted from Cumberland Public Service, it could still fail to meet the requirements of section 331 for purposes of determining the tax treatment of the shareholders.

Judge Tannenwald is not particularly clear about the type of commercial motivation which he would require for a liquidation to qualify for section 331 treatment. If his position is to become the foundation for future interpretation of section 331 , it will be necessary to clarify that requirement.

A rather clear case can be made for focusing on shareholder motivation. First, it is clear that the question will not even arise if the business of the corporation is not continued by a new corporation. If the liquidation transaction results in the business being wound up or permanently conducted in noncorporate form, there is no reason why the transaction would not qualify under section 331 . Whoever has made the decision to liquidate has acted from a motivation which has clear commercial, non-tax significance; the liquidation brings to an

55. 338 U.S. 451 (1950).

56. Id. at 455 . 
end the ownership of the business by a corporation. But even in describing this relatively simple case, the dominance of shareholder motivation is evident. It is the shareholders who make the decision to liquidate; the managers and the board of directors may recommend it, but the shareholders have the final responsibility for the decision.

Shareholder motivation becomes even more clearly dominant when reincorporation of part or all of the business follows the liquidation. Once the liquidation has occurred the shareholders are the only possible persons involved in the subsequent decision to reincorporate since they then directly own all the assets of the defunct corporation. Furthermore, they decide which of the assets will go into the new corporation and which will be held out. Thus, the shareholders have the ultimate decision on three important matters: first, the liquidation of the old corporation; second, reincorporation; and third, the retention of some assets. Whether the transaction takes the form of that in Lammerts, which was an uncomplicated liquidation and reincorporation, or one of the more sophisticated forms such as in Reef or Davant, the motivation behind those three steps, no matter in what order they occur, will control the final shape of the transactions. Thus, it is the combination of the three steps that creates the tax issue..$^{57}$

It may be helpful at this point to divide liquidationreincorporation cases into two categories, the difference between the two being whether, at the time of the liquidation, there is an intention to reincorporate. If no such intention exists, then no overall purpose or motivation is behind the entire sequence of events; the purpose for liquidating would be much the same as that in cases where no reincorporation follows. Recently, in William C. Kind ${ }^{58}$ the Tax Court faced that situation. In May, 1962, Kind, a retail florist, dissolved the corporation which he owned and continued his florist business as a sole proprietorship. In July, 1962, he became interested in manufacturing and marketing a new plant food as an adjunct to his florist shop. Because of the risks of this new undertaking, in January, 1963, he incorporated his entire business. The absence of an overall plan for liquidating and then reincorporating was the basis for rejecting the Commissioner's argument that these two events were

57. The same issue would possibly arise if no assets were retained in the reincorporation. Such a transaction might be motivated by the idea of getting a stepped-up basis for assets at the expense of a capital gains tax on the liquidation of the old corporation.

58. 54 T.C. 600 (1970). 
only parts of a single transaction. Accordingly, no reorganization was found. However, treating each step as a separate transaction does not necessarily determine whether the liquidation should qualify under section 331. It might still be possible that the motivation involved in the decision to reincorporate, even though that decision is made after the liquidation, may be sufficiently "tainted" to disqualify the liquidation from section 331 treatment. ${ }^{59}$ This argument would be strengthened if the taxpayer did not put all of the assets from the old corporation into the new corporation. If only part of the corporate assets are transferred to the new corporation, there should again be an inquiry into shareholder motivation: what is the motive for retention of some of the assets? In Kind, as an example, why did the taxpayer fail to reincorporate all of the assets? This inquiry would likely support a finding that the original liquidation was "tainted," or the retention of the assets probably had a tax motivation even if the liquidation did not.

However, a difficulty with rejecting section 331 treatment in the Kind situation appears immediately. Treating the liquidation as a separate taxable event but rejecting its qualification under section 331 would apparently require that the shareholders be taxed on the entire distribution, even though a substantial portion of the assets eventually goes back into the corporate solution. If section 331 does not apply, then it is necessary to determine whether gain is measured in the same way as in a liquidation - the difference between the fair market value of the assets and the basis of the stock ${ }^{60}$-and whether tax is levied on that amount, or whether the transaction is taxed as a distribution under section 30l. If the latter approach were adopted, the distribution would be accorded dividend treatment under sections 301 and 316 to the extent of earnings and profits, and any remaining amount would be first a reduction of basis and then a capital gain distribution. ${ }^{61}$

The most plausible choice between these two alternatives would

59. Kind also recognized that qualification under section 331 is not dependent on dissolution under state law. Id. at 605, citing Pridemark, Inc. v. Commissioner, 345 F.2d 35, 41 (4th Cir. 1965).

60. INT. REV. CODE of 1954, § 1001 (a)-(b).

61. Id. $\S 301$ (c). If the transaction were not deemed to be a section 301 distribution and if gain is only realized to the extent that the amount realized exceeded basis, then such gain would be ordinary income, not because of the presence of earnings and profits of the corporation, but because, in the absence of section 331 coverage, there is no sale or exchange sufficient to warrant capital gain treatment. Id. $\S 1221$. 
appear to be section 301 treatment since there would be a distribution with respect to stock. But, in that case, all of the accumulated earnings and profits of the corporation would be taxed as an ordinary dividend whether the shareholder had a gain or not. For example, suppose a taxpayer acquired all of the stock of a corporation for $\$ 100,000$ at a time when the corporation's net book value was $\$ 100,000, \$ 90,000$ of which consisted of accumulated earnings and profits. If the shareholder then liquidated the corporation in a transaction that did not qualify under section 33l, even though the shareholder would realize no gain, section 301 would require that he be taxed on a dividend of $\$ 90,000$. The remaining $\$ 10,000$ would be offset against his basis of $\$ 100,000$, and he would be left with a basis of $\$ 90,000$ which would essentially disappear. ${ }^{62}$ Now consider further that this shareholder subsequently put all but $\$ 25,000$ worth of the assets back into corporate solution; this reincorporation being the act which prevented the liquidation from qualifying for section 331 treatment. The inequity of section 301 treatment is then apparent. If the shareholder had the purpose of reincorporating at the time of liquidation, he would have been treated as receiving either a dividend of $\$ 25,000$-if the transaction were held to be the equivalent of a simple distribution of a dividend-or a return of capital, with no tax, if the transactions were linked together to find a reorganization with the $\$ 25,000$ being a boot distribution. ${ }^{63}$ Thus, the shareholder setting out on a liquidation-reincorporation scheme to bail out earnings and profits would be treated less harshly than the shareholder who had no intention of reincorporating or bailing out earnings at the time he liquidated the corporation. This inequity would argue persuasively for either rejecting section 301 treatment in favor of limiting the income to that gain equal to the amount received over the basis, or accepting the Tax Court's result in the Kind case. ${ }^{64}$

62. The distribution would not first be offset against basis because section 301 (c)(1) requires ordinary income treatment to the extent that the distribution is out of earnings and profits. Section 301 (c)(2) would thus appear to apply only to the $\$ 10,000$ which is not part of carnings and profits. Of course, if there were a change in shareholder interest (for example, if two people had bought the original corporation and one shareholder received no stock in the new corporation), it might be said that this was in effect a redemption of the stock of the shareholder whose interest had changed. In that case, section 302 would require that such sharcholder receive capital gain treatment.

63. Since there would be no gain, the limitations of section 356 (a) would result in there being no tax.

64. Although, when one posits the absence of any motivation to reincorporate, the holding of the Kind case has great appeal, one cannot forget the difficulty of determining the absence of 
The second category of liquidation-reincorporation cases is, of course, the one where an intention to reincorporate exists at the time of the liquidation. In the example used above, where the shareholder had no gain on the exchange, the issue is clearly posed as to whether the reorganization provisions ${ }^{65}$ are the most realistic way of determining the tax on such a transaction. If they are so considered, there would be no tax under section 356 on the bail-out because this shareholder had no gain. If, however, the distribution and retention of the $\$ 25,000$ is considered to be "functionally unrelated" to the remainder of the transaction and is treated as a separate taxable event, it would be taxed as an ordinary dividend. A consideration of the overall motivation behind the transactions may be the only way to make a choice between the two alternatives.

However, if Judge Tannenwald's approach is taken, the liquidation is ignored because no commercial motivation exists; it is not accorded section 331 treatment because the corporate existence is considered to have continued unimpaired. Similarly, since there has been no liquidation for tax purposes, there can be no " $D$ " reorganization and no boot distribution. ${ }^{66}$ Accordingly, the removal of $\$ 25,000$ from corporate solution must be viewed as a simple distribution, taxable as a dividend. Obviously in this type of case little differentiates the functionally unrelated approach and the decision that no liquidation occurred. Both approaches turn on the question of the intent for undertaking the transactions. In the simple case, there may be no valid commerical reason for the steps except to obtain a distribution without tax; in a more complex case, a variety of reasons for the series of events may exist.

Such a case was recently before the Tax Court in American Manufacturing Co. ${ }^{67}$ In that case a domestic subsidiary (Pintsch) of a U.S. corporation sold its assets to a Canadian subsidiary (I.S.I.) of the U.S. company for cash and then liquidated. Under these facts, the Tax Court had little difficulty in finding that a " $D$ " reorganization had occurred. There was a transfer of assets by Pintsch to I.S.I., both controlled by the common parent, in exchange for stock and boot,

that motive at the time of liquidation, and a rule that would eliminate that determination in a case like Kind would greatly ease the administration of the law.

65. INT. REv. CoDE of $1954, \S \S 35 \mathrm{I}-68$.

66. Id. $\S 368(\mathrm{a})(\mathrm{I})(\mathrm{D})$ requires a distribution which qualifies under sections 354,355 , or 356; section $354(\mathrm{~b})(\mathrm{I})(\mathrm{B})$, the section pertinent here, requires a liquidation for the distribution to qualify in a " $D$ " reorganization.

67. 55 T.C. 204 (1970). 
followed by a liquidation of Pintsch. Difficulties concerning compliance with section 354(b)(1)(A)'s requirement of a transfer of "substantially all" of Pintsch's assets to I.S.I. were handled by using the definition of "substantially all" of John G. Moffat; $; 8$ a similar difficulty with compliance with the requirement of sections 354 and 368 of an exchange of stock was met by applying the constructive issuance of stock rule of James Armour, Inc. ${ }^{69}$ That left the Tax Court with the question of whether the removal of the cash that was distributed to the parent company from the corporate solution was functionally unrelated to the " $D$ " "reorganization. Facing the issue of intent, the Tax Court said it was unnecessary to prove any business reason to couple the distribution with the reorganization; it was enough that the parties wanted to do so.

Congress recognized that legitimate reorganization could take place concurrently with distributions of "other property" that had the effect of a dividend. In effect, this distribution "dividend" is unnecessary to, or "unrelated to" the legitimate reasons for the reorganization and Congress realized this. We think this is clearly evidenced by the committee reports accompanying the enactment of section 203(d)(2). . . .70

The . . committee report indicates that when distributions other than stock were received in connection with a reorganization, and had the effect of a dividend, the distributions were to be governed by section 203(d)(2)."

The Tax Court then emphasized its statement, italicized in the above quote, that the proper test is whether the distribution occurs "in connection with" the reorganization:

We hold that the distributions herein must be treated under section 356(a)(2). They were made in connection with an overall scheme of events, constituting a section $368(a)(1)(D)$ reorganization and fall within the intent and purposes of section 356(a)(2) treatment. ${ }^{72}$

Once again Judge Sterrett differed on the importance to be accorded to the question of intent. He pointed out that whatever the (1967)

68. 43 T.C. 558 (1964), affd. 363 F.2d 262 (9th Cir. 1966), cert. denied, 386 U.S. 1016

69. 43 T.C. 295 (1964).

70. At this point the court quoted from H.R. REP. No. 179, 68th Cong., Ist Sess. 14-15 (1924). 55 T.C. at 227. The Tax Court's reliance on this report for its conclusion seems misplaced. The report actually reveals the Committee's lack of sophistication with liquidationreincorporation devices-not so strange considering that it was written in 1924-but clearly shows its desire to treat distributions related to reorganizations in the same way that dividends were then treated.

71. 55 T.C. at 227.

72. Id. at 228. 
reason that may have existed for the " $D$ " reorganization, it was fully accomplished by a transfer of assets from one subsidiary to another; no commercial reason existed for the cash transfer and resultant bailout of earnings.

It is difficult to conceive of the business necessity for using cash as the consideration for the transfer. Absent an explanation as to why the exchange was not made in the usual manner, a realistic conclusion to be reached is that Safety, as the sole shareholder of both Pintsch and 1.S.I., availed itself of the opportunity to siphon off the excess cash from 1.S.l. by running it through Pintsch and lumping it with the latter's liquidating distribution.

It would seem difficult to conclude from the facts in this case that the cash transfer was in any sense an integral or even appropriate, part of the reorganization. Having accepted the fact of a reorganization we are under no compulsion to permit the parties to sweep all other exchanges under the same protective umbrella merely because they were made to occur at the same time. To do so would be to allow the statutory scheme to be subverted. ${ }^{73}$

Here there was a non-tax, commercial purpose for the transfer of assets from one subsidiary to another and that transaction was not undertaken primarily as a means to siphon off cash from the subsidiary; the transfer of assets could stand on its own reality and be accepted as a "D" reorganization. In this sense, American Manufacturing Co. differed from Casco Products Corp. ${ }^{74}$ where the "reorganization" was undertaken to achieve a redemption of the shares of a dissenting minority of shareholders, and from Lammerts, where the liquidation-reincorporation was clearly motivated by a desire to bail out earnings by distributing property. In both Casco and Lammerts, Judge Tannenwald's approach was to ignore the liquidation. In American Manufacturing $C o$., the liquidation was also ignored-it was not accorded section 332 status-but the reason was quite different. There was a business motivation for the transfer of assets from one corporation to another, but the transfer was part of a plan which the Tax Court majority, including Judge Tannenwald, found to be equivalent to a " $D$ " reorganization. Thus, it seems clear that Judge Tannenwald is examining the motivation of the shareholders in accomplishing the entire sequence of transactions. If there is valid commercial motivation for the reincorporation, apart from the desire to give favorable tax treatment to the bail-out of earnings and profits, then Judge Tannenwald apparently would accept the validity of the entire transaction; if it appeared to be a

73. Id. at 233 (emphasis added).

74. 49 T.C. 32 (1967). 
reorganization, he would reject the functional independence test and permit the parties, as Judge Sterrett so aptly put it, "to sweep all other exchanges under the same protective umbrellä merely because they were made to occur at the same time. ${ }^{75}$

It is ironic in a way that these two judges should differ on this concept of functional independence. With Judge Tannenwald's heavy reliance on motivation in determining whether a transaction should be viewed as a liquidation, a reorganization or a simple distribution, it is strange that he would reject the test of commercial motivation in deciding whether a transaction should in all cases be treated as functionally related to the other events which take place. Clearly, the two approaches are not mutually exclusive. No reason appears why the two judges could not differ on their approach to the Lammerts case and still agree on American Manufacturing Co. It is quite possible that Judge Tannenwald could view a series of events as not accomplishing a section 331 liquidation and, further, believe that one of the events is so functionally unrelated to the rest that it should be considered a separate transaction. If he adopted that view, Judge Tannenwald would probably have joined Judge Sterrett in dissent in American Manufacturing Co. even though they wrote separate opinions in Lammerts.

\section{A COURSE For THE FUTURE}

It is predictable that any judicial solution to the liquidationreincorporation problem will grow out of one of these three separate approaches described in Lammerts. Perhaps the functional independence test will be expanded to exclude steps that had previously been considered a part of the reorganization transaction, or perhaps the definition of liquidation will be limited so that those liquidations that are not intended to, and do not, end in the removal of a going business from the umbrella of a corporation do not receive section 331 capital gains treatment.

If neither of these approaches can gain additional support in the courts, and if the rigid approach of the majority of the Tax Court continues to dominate judicial treatment of liquidation-reincorporation transactions, it seems likely that Congress will once again have to consider a statutory solution. Congressional responses to loopholes in the taxing scheme are traditionally sledgehammer

75. 55 T.C. at 233. 
approaches with all the grace and refinement of a whale out of water. This is not intended as carping criticism; when Congress deals with a problem it is forced to deal in generalities and is under some constraints about the breadth of the solution. When a court deals with a tax problem, it deals with a specific problem and is not under the same constraints. Thus, the judicial solution is likely to be more sophisticated, less blunt, and more selective in its application. For this very reason the courts should free themselves from the "tyranny of labels" to which Judge Tannenwald refers and deal realistically and reasonably with the Code and its policy, with sympathy not only for taxpayers but also for the public. Were they to do so, the courts could forge a far better taxing instrument, one capable of greater equity and less abuse than Congress can ever hope to achieve if courts continue to peevishly insist that if Congress didn't intend a particular result, it should not appear to say that it did.

Should the courts take a sufficient interest in tax policy to turn their abilities to achieving a more reasonable approach to liquidationreincorporation problems, it seems likely that motivation will play a substantial part in their decisions. In Judge Sterrett's approach it will be important to determine whether there is a commercial motivation for coupling the particular step with the reorganization transaction. If a substantial non-tax motivation can be found, then the functional independence doctrine will not override the step transaction theory in binding steps together if they are taken pursuant to a single plan. If Judge Tannenwald's theory prevails, then the existence of commercial motivation, principally that of the shareholders, will assume importance in determining whether a liquidation transaction is considered a sham, but there will continue to be a strong bias for treating all contemporaneous events as part of the liquidation, reorganization, or distribution transaction. Finally, the two approaches may merge, with the courts requiring commercial motivation for recognition of liquidations as well as for transactions that could be viewed as having independent functions. Since these approaches will all depend on non-tax motivations, tax counselors would do well to examine carefully the reasons for proposed transactions and caution clients about the changing nature of the law in this area of liquidation-reincorporations before proceeding with transactions that are primarily motivated by attempts to avoid the full impact of the corporate income tax. 
